Chirurgia (2021) 116:599-608

No. 5, September - October

Copyright@ Celsius

http://dx.doi.org/10.21614/chirurgia.116.5.599

\title{
Plasma Derived Products for Polypropylene Mesh Integration in Abdominal Wall Defects: Procedure Description and Partial Results
}

\author{
Valentin Popescu ${ }^{1 *}$, Traian Pătrașcu², Dan Andraș ${ }^{1}$, Marius-Septimiu Petruțescu', Sergiu Cecoltan ${ }^{3}$, \\ Izabela-Cristina Stancu ${ }^{3}$, Bogdan-Stelian Mastalier-Manolescu ${ }^{1}$ \\ 'Department of General Surgery, Colentina Clinical Hospital, Bucharest, Romania \\ "General Surgery Department, "Dr. I. Cantacuzino" Clinical Hospital, Bucharest, Romania \\ ${ }^{3}$ University Politehnica of Bucharest Advanced Polymer Materials Group, Bucharest, Romania
}

*Corresponding author:

Valentin Popescu, MD

Department of General Surgery

Colentina Clinical Hospital

19 - 21, Stefan cel Mare, 72202

Bucharest, Romania

E-mail: popescu.vali.umf@gmail.com

Received: 21.02.2021

Accepted: 19.04.2021

\section{Rezumat}

Produse derivate din plasmă utilizate pentru integrarea plaselor herniare polipropilenice la nivelul peretelui abdominal: descrierea procedurii și rezultate parțiale

Introducere: Chirurgia peretelui abdominal presupune implantarea unui tip de proteză (plasă) în tesutul înconjurător deasupra sau sub stratul fascial al peretelui abdominal. Cel mai utilizat material pentru protezare este polipropilena, care uneori necesită mult timp pentru a fi integrată în țesut fibros 1,2. În încercarea de a accelera integrarea plasei şi astfel pentru a creşte rata de recuperare postoperatorie, am dezvoltat un protocol cu produse derivate din plasma pacientului pentru a accelera integrarea protezei. Fibrina bogată în trombocite (PRF) şi plasma bogată în trombocite (PRP) au fost evaluate în promovarea sintezei de colagen şi a proliferării celulare pe suprafața ochiurilor.

Material şi Metode:Am evaluat 32 de pacienți cu diferite tipuri de defecte parietale abdominale care au necesitat implanturi de plasă din polipropilenă în chirurgia deschisă, cu plasă implantată supraaponevrotic. Am împărțit pacienții în 3 grupuri: procedura standard, ochiuri augmentate numai cu PRF, ochiuri augmentate numai cu PRP.

Rezultate: Chiar dacă numărul pacienților implicați în studiu are un impact foarte mic pentru o analiză statistică, modelul observat în studiul nostru prospectiv relevă de la început că mărirea 
procedurii standard cu produse derivate din plasmă îmbunătățeşte rezultatul (integrarea rețelei) până la 65\% integrare mai rapidă.

Concluzie: Tehnica pe care am folosit-o pentru a augmenta implantul standard este rentabilă şi simplu de utilizat în sala de operații.

Cuvinte cheie: PRP, PRF, produse derivate din plasmă, integrare plasă, integrare proteza din polipropilenă, augmentarea reparatiei peretelui abdominal

\begin{abstract}
Introduction: Abdominal wall surgery for parietal defects is done by implanting a type of mesh in the surrounding tissue above or beneath the fascia layer of the abdominal wall. The most common type of mesh used is polypropylene which sometimes takes a lot of time to be covered by the fibrous tissue1,2. In an attempt to accelerate the cellular binding on the mesh and so to increase the recovery rate, we developed a protocol with plasma derived products to accelerate the mesh integration. Platelet rich fibrin $(\mathrm{PRF})$ and platelet rich plasma $(\mathrm{PRP})$ were evaluated in promoting the collagen synthesis and cell proliferation on the mesh surface.

Material and methods: We evaluated 32 patients with different types of abdominal wall defects which required polypropylene mesh implants in open surgery with the mesh implanted above the aponeurosis layer. We divided the patients into 3 groups: standard procedure, mesh augmented with PRF only, mesh augmented with PRP only.

Results: Even though the number of patients involved in the study has a very small impact for a statistical analysis, the pattern observed in our prospective study reveals from the beginning that augmenting the standard procedure with plasma derived products improve the outcome (mesh integration) up to $65 \%$ faster integration.

Conclusion: The technique that we used to augment the standard implant is cost-effective and simple to use in the surgical theatre.
\end{abstract}

Key words: PRP, PRF, plasma derived product, mesh integration, polypropylene mesh integration, abdominal wall repair augmentation

\section{Introduction}

Polypropylene meshes for abdominal wall defects are widely spread due to their strength, but they have a disadvantage that is common in all sorts of implants: tissue integration (1-4). From the variety of types of polypropylene meshes, knitted macroporous have the adequate strength and a low risk of infection, but seroma is a usual complication which delays the fibrous reaction and proper mesh integration $(5,6)$. For the body to embed the implanted prosthetic mesh properly several parameters are essential: aseptic procedure for the implant, good haemostasis at the surgical site, a good tension free fixation technique which prevents rolling or loosening of the mesh and a firm contact with the adjacent connective tissue from which fibrous cells migrate on the mesh surface $(2,7-9)$. The surrounding connective tissue provides the cells needed for mesh coverage. The inflammatory process generated by the polypropylene prosthesis generates the biochemical stimulus for the migration of fibroblasts $(3,6)$. If the inflammatory response is of exaggerated intensity, it will generate the production of proinflammatory cytokines such 
as tumor necrosis factor alpha (TNFa) or interleukin 6 (IL6), thus altering tissue integration. The gap between the implant and the connective tissue around generates extracellular fluid accumulation which alters the integration dynamic and could compromise it. So the typical solution to this problem is either suturing the planes in an attempt to close the space between the prosthesis and the tissue or placing a preprosthetic drain. We developed a third option by using the patient's plasma to act as a matrix for the developing fibroid tissue and also reduces the infectious complications rates $(10,11)$.

To improve the outcome and minimise the contact between the mesh and tissues around we added plasma derived products such as platelet rich plasma (PRP) and platelet rich fibrin (PRF) on the mesh surface. They are autologous and enriched with growth factors, and matrix forming molecules $(10,12-18)$. PRP is used to reduce inflammatory processes in soft tissue and improve tissue growth. Also some products such as PRF come with leucocytes which enhance the local defence mechanism $(11,12,19,20)$. The biological layer created on the mesh area is supposed to act as a soft tissue matrix enriched with growth factors and also protect the mesh from pathogens $(10,11)$.

PRF is beginning to be used as a biological scaffold and growth factor generator in all sort of tissue defects with good results $(10,16,20$, 21). The key part of this therapy is the fact that the matrix is fully absorbable and fully tolerated by the body (autologous material).

The aim of this study is to analyse the structure and the behaviour of the plasma derived products in relation to the polypropylene mesh.

\section{Material and Methods}

The study setup was divided in two parts: the first part consisted in in-vitro studies of the mesh behaviour with the plasma derived products, and a second part for evaluation of the standard procedure improved with plasma derived components.
In the in-vitro part of the study, we evaluated the polypropylene mesh behaviour on a macroscopic and microscopic level when in contact with the PRP and PRF.

The mesh used for the whole study was HerniPro Type P3 and P4 meshes (Biosintex).

For the macroscopic and microscopic assessment we used blood samples from a single volunteer. We used whole venous blood from which we made PRP in citrate tubes and blood cloth tubes for PRF. The PRP used for macroscopic and microscopic evaluations had a 6 fold concentration of platelets in comparison with patient plasma. For macroscopic testing we used the PRP and PRF as obtained from the centrifugation process applied on 4 mesh samples (2 samples for each mesh typeP3 and P4 and a PRP and a PRF sample for each mesh type). The test was conducted in a sterile operating room using sterile sheets on the working table and a triple manipulation process at 24 degrees Celsius. We applied on the mesh surface patches of PRP and PRF. Because PRP is in a liquid state, it diffuses between the mesh pores, so the distribution along the mesh surface is uneven. We also evaluated the cell growth on the mesh on a microscopic scale.

For microscopic observations, we used predefined concentrations of PRP to see if there is a difference in fibroblastic growth. In the final PRP preparation stage for in vitro measurements the PRP solution was debunked using an ultrasonication bath for 5 minutes and centrifuged again at 2500G for 7 minutes. From this concentrated PRP we used 2 predefined concentrations.

The fibroblast used were murine fibroblasts from the L929 line cultured in Dulbecco's Modified Eagle Medium- DMEM (Sigma) supplemented with 10\% Bovine Fetal Serum (SFV- Biochrom), Penicillin and streptomycin (Sigma); trypsin- Ethylenediaminetetraacetic acid (EDTA) solution, Saline Phosphate Buffer (PBS-1x Sigma), 96-well plates 3300-TCP and 3474(Ultra low attachment surface-ULAPLCostar).

The meshes were cut into circular shape with the $6.1 \mathrm{~mm}$ diameter to fit in to the plate 
wells. The tested meshes were decontaminated using a 20 fold antibiotic solution of penicillin and streptomycin for 2 hours. The samples were then transferred on the plate and fixed on the bottom of the well using a PP gasket. All the samples were made in sterile conditions and washed 5 times with PBS.

The first step was an evaluation of the polypropylene meshes with or without plasma derived products on the surface on a macroscopic and microscopic level in order to characterise the plasma products.

For the outcome evaluation and effectiveness of the augmentation, the second part of the study evaluated 8 cases of abdominal wall defects ( 2 umbilical hernias, 4 inguinal hernias and 2 periumbilical midline incisional hernias) from October 2017 that were evaluated for a minimum of 1 month after discharge. The umbilical hernia batch had enrolled a 35 year-old (yo) male and a 46 yo female, the inguinal hernia batch had enrolled 3 male patients aged between 56yo and 70yo and one female age 71 and the midline incisional hernia group that was composed of 1 female 62yo and 1 male 46yo. All the selected patients had no record of malignancies and no infections at the time the surgery was performed. The patients were selected randomly from the study group, and the surgical team was informed intraoperative to follow the augmented procedure in a doubleblind manner. All the patients enrolled had normal platelet counts and normal haemoglobin levels before surgery.

After the preliminary results from the first stage of the study, we developed an intraoperative protocol for using $\mathrm{PRP}$ and PRF intraoperative (the preparation of the blood started when the surgical team began the onlay mesh fixation). The kit for plasma derived products can be seen in Fig. $1 A$.

All the defects were repaired using monofilament small pore polypropylene meshes (HERNI PRO, mesh type P3BioSintex) anchored with polypropylene sutures due to its good tensile strength, good tissue integration and low infection risk (1). All abdominal wall defects were repaired in an open manner using the onlay technique.

The plasma derived products were obtained intraoperative from fresh venous blood using a Portafuge model E8 centrifuge at $3300 \mathrm{rpm}$ and used immediately after. For PRP we used $2.8 \mathrm{ml}$ citrated vacutainers (BD Vacutainers), and for PRF, Clot activator $9 \mathrm{ml}$ vacutainers (Vacutest Kima). After the mesh was secured in place with sutures we applied either the PRF on the mesh surface using multifilament, synthetic, polyglycolic acid absorbable surgical suture size 0, (Bicril, BioSintex).

We used PRP in 2 inguinal hernias where the prosthetic implant was small in diameter, due to the lack of higher capacity vacutainers with citrate, which would have enabled us to obtain more than $1 \mathrm{ml}$ of PRP for bigger mesh coverage. We used between 2 and 6 cloths of PRF per augmentation adapted to the mesh surface area needed to be covered. We applied one 1/1/3 cm PRF cloth for every $2 \mathrm{~cm}^{2}$ of poly-propylene mesh. The augmentation process can be seen in Fig. $1 B$.

The patients were evaluate by soft tissue ultrasound using TOSHIBA NEMIO XG ultrasound machine before the surgery, the day after surgery, at one week, at two weeks, and at one month after the surgery. We evaluated the gap between the fat tissue and the mesh, the thickness of the mesh layer, measured using the ultrasound device soft-

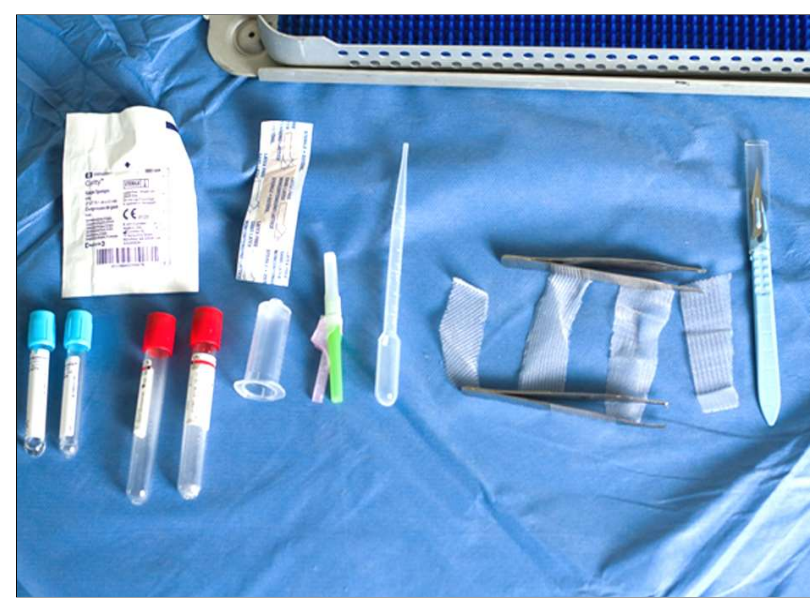

Figure 1A. The PRP/PRF augmentation kit content from blood sampling to mesh surface coverage 


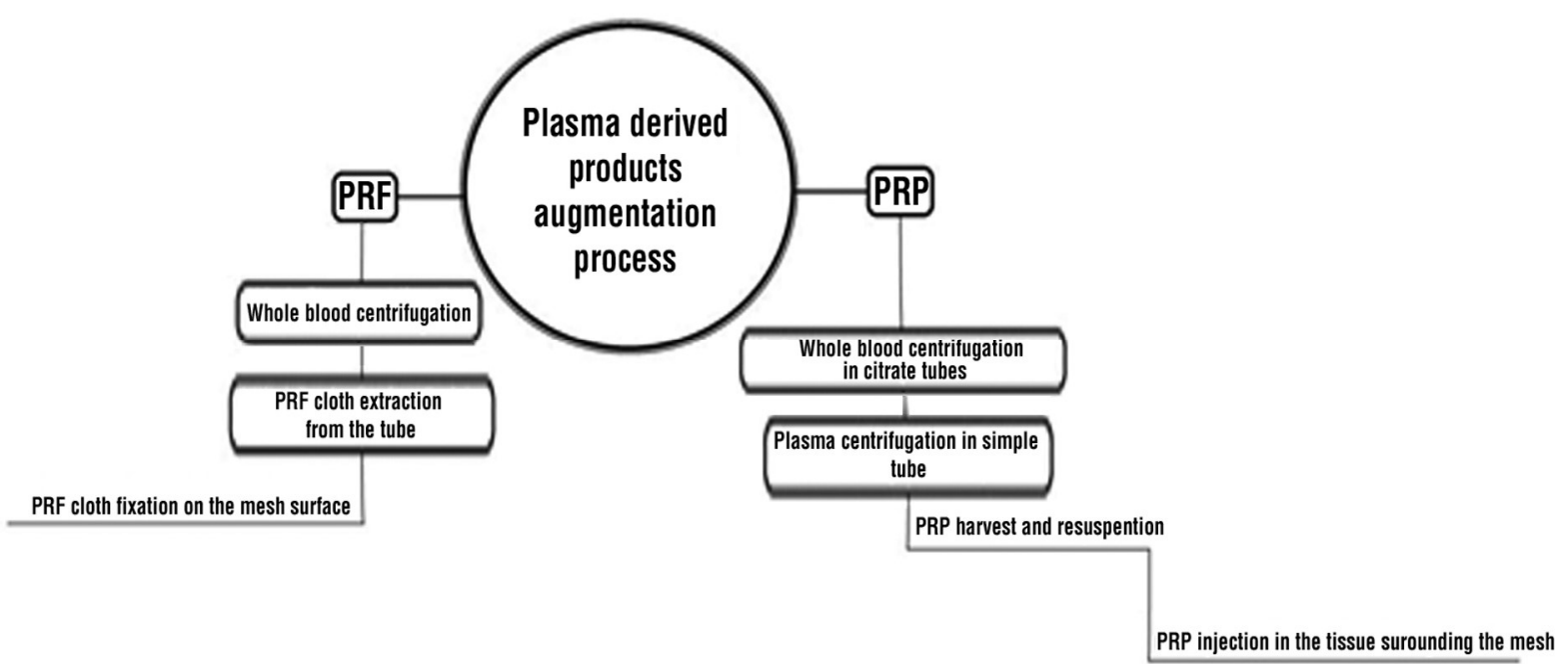

Figure 1B. The algorithm for obtaining specific plasma derived products for the mesh coverage

ware pack, the presence of liquid colections on the surgical site and compared the data with data obtained from our Clinic database from standard treated patients.

\section{Results}

The initial phase of the study revealed that on a macroscopic level, PRP covered the whole surface of the mesh including the mesh pores, but the coverage is dependent on the gravitation when applied on the surface, so it generates uneven coverage of the mesh. The PRP even in small concentrations generates a proper development interface for the fibroblastic cells to cover the mesh surface. When applied directly on the mesh surface, the type 4 HerniPro allows PRP to merge between the pores, while the type 3 creates a surface tension which allows the PRP to flow on the surface (Fig. 2).

PRF on the other hand needs suturing fixation on the surface of the mesh to obtain a good surface coverage and ads between $2 \mathrm{~mm}$ and $6 \mathrm{~mm}$ in thickness (Fig. 3).

These observations suggest that PRP should be used by infiltration in the surrounding tissues for generating a high-density area of

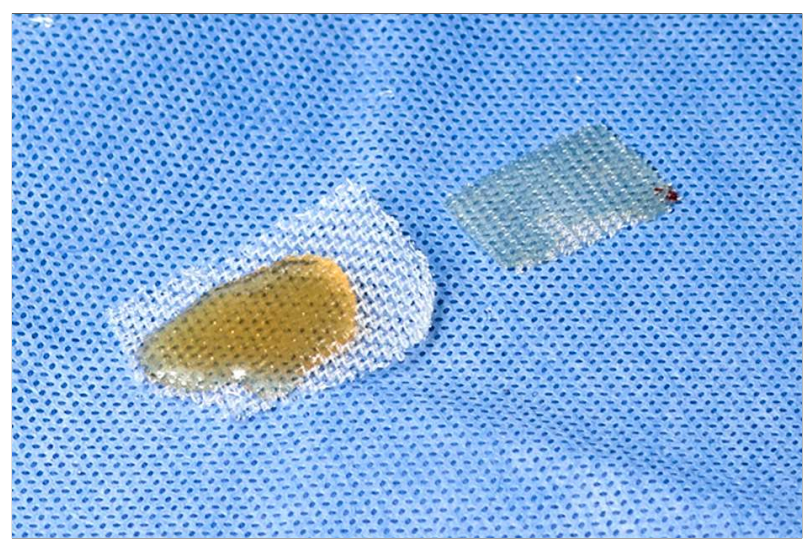

Figure 2. PRP on a microporous mesh with the initial surface tension

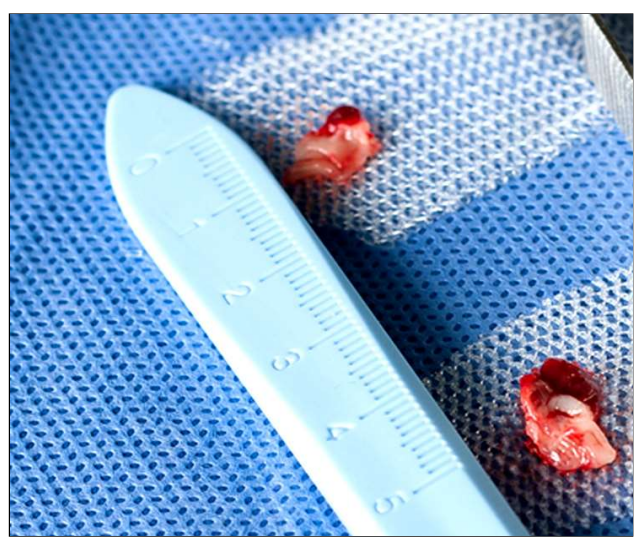

Figure 3. PRF clots dimensions versus pore size 

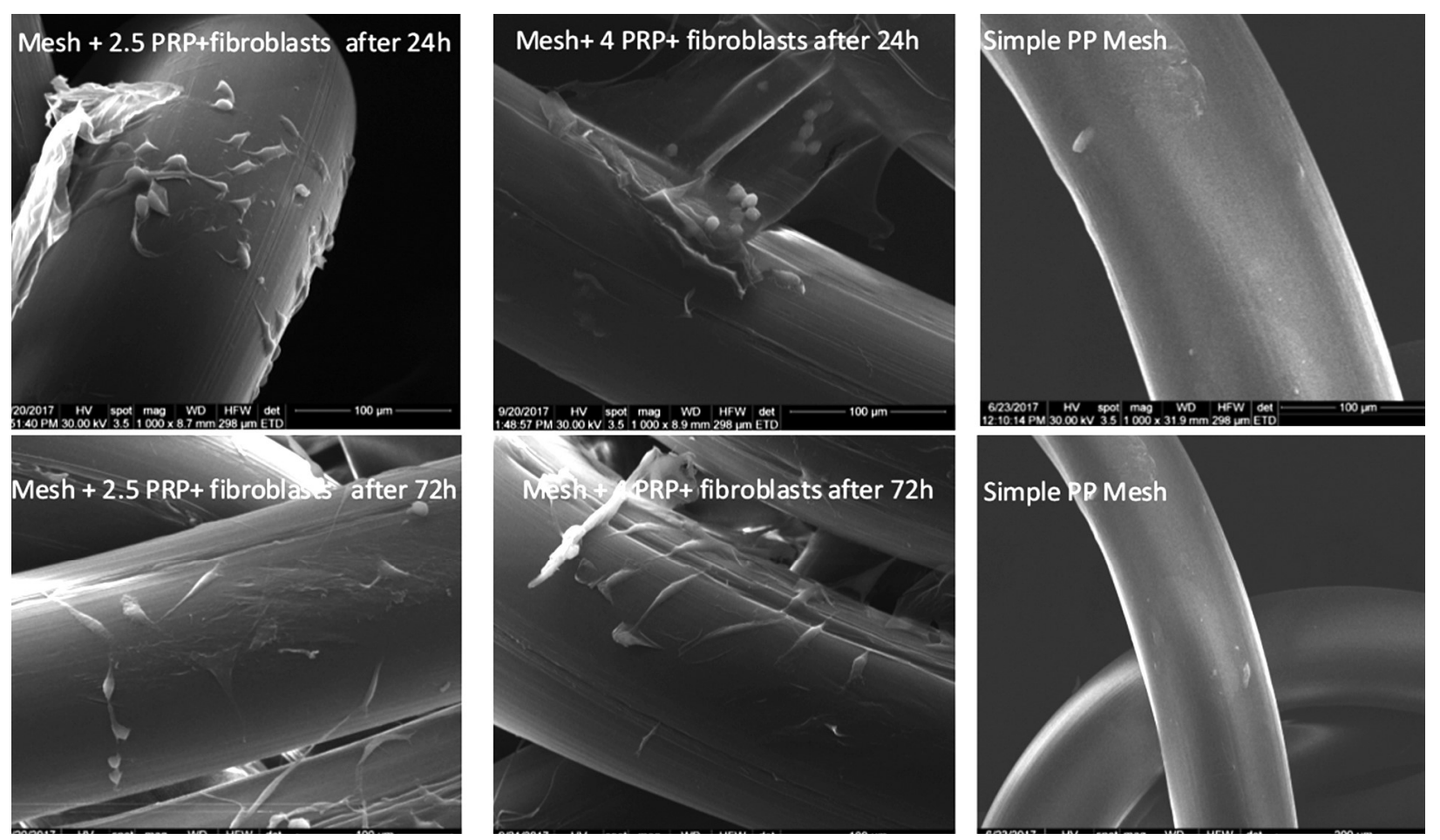

Figure 4. Polypropylene mesh behavior when in contact with PRP.

We can observe that higher conccentrations of PRP generates as expected a better cellular coverage of the mesh surface, but also creates interfiber connections in the micropores of the mesh. The cellular growth after 72 hours shows that the cells from the PRP are still viable

growth factors and induce the growth stimuli. After the SEM analysis of the meshes treated with different concentrations of PRP (2.5 fold and 4 fold), the results shows that the meshes augmented with PRP are better populated with fibroblasts than the untreated mesh after 24 hours and after 72 hours with minimal difference between them (Fig. 4 ).
PRF acts as an active growth matrix, which reduces the virtual space between the mesh and the surrounding tissue. The comparison between the techniques used for hernia repair from Table 1 show that using plasma derived products does not influence significantly the duration of the surgery, and has just a few precautions which are related with the quality

Table 1. Comparison on plasma derived products in polypropylene mesh integration vs standard procedure

\begin{tabular}{llll}
\hline & Mesh only & PRP & PRF \\
\hline General & & No & Yes \\
\hline Mesh surface modifications & No & Minimal infiltration after the injection & Virtual space coverage \\
\hline Surrounding tissues modifications & Local inflammatory reaction & Intraoperative infiltration of the soft tissues & $\begin{array}{l}\text { Suture fixation on the mesh } \\
\text { surface }\end{array}$ \\
\hline Appling technique & $\begin{array}{l}\text { On lay suturing } \\
\text { (above the aponeurosis) }\end{array}$ & 10 minutes to mesh only technique & 14 minutes to mesh only technique \\
\hline Preparation time & $5-15$ minutes & Low platelet count infections & Low platelet count infections \\
\hline Precautions & Usual for hernia repairing & No wound drainage for the first 24h & No wound drainage for the first 24h \\
\hline Special & & +10 minutes & +14 minutes \\
\hline Special needs (technique related) & No & 1-2 Citrate tubes $5 \mathrm{ml}$ and 2-4 citrate $2.8 \mathrm{ml}$ & $2-6$ Blood Clot $9 \mathrm{ml}$ tubes
\end{tabular}


Table 2. PRP vs PRF action mechanism

\begin{tabular}{|c|c|}
\hline PRP & PRF \\
\hline Used in the first 30 min after preparation & $\begin{array}{l}\text { Used after cloth drying }(10 \mathrm{~min}) \\
\text { but not more than } 3 \text { hours }\end{array}$ \\
\hline Immediately after injection & After tissue closure and perfusion \\
\hline *High speed fibrin formation & $\begin{array}{l}\text { *Physiological speed fibrin } \\
\text { formation }\end{array}$ \\
\hline${ }^{\star}$ Tetramolecular fibrin fibers & ${ }^{*}$ Trimolecular fibrin fibers \\
\hline${ }^{\star}$ Poor immunomodulatory properties & $\begin{array}{l}\text { *Good immunomodulatory } \\
\text { properties }\end{array}$ \\
\hline${ }^{\star}$ Small neo-angiogenetic properties & $\begin{array}{l}\text { *High neo-angiogenetic } \\
\text { properties }\end{array}$ \\
\hline *Mesenchymal stem cells present & $\begin{array}{l}\text { *Mesenchymal stem cells } \\
\text { present }\end{array}$ \\
\hline No mechanical properties & $\begin{array}{l}\text { Good mechanical properties } \\
\text { (it can be sutured) }\end{array}$ \\
\hline
\end{tabular}

of the product. As seen in Table 2, from the mechanism of action, $\mathrm{PRF}$ is better in covering tissue defects, while PRP is better in adjusting the tissue healing process. The PRF was secured on the mesh surface using Bicril $^{\circ} 0$ sutures when used in therapy (Fig. 5).

In 6 cases (all in which the PRF was used) the evaluation after a week was similar with the aspect of the standard treatment after 4 weeks after surgery, with an average of $64 \%$ of the mesh length covering the gap between the mesh and fat tissue, 2 cases with $30 \%$ coverage (the cases where only PRP was used) comparing with $27 \%$ coverage with a mean of $3.2 \mathrm{~mm}$ gap for the standard surgical technique. After 1 month all the implants seemed completely integrated in fibrous tissue, and no liquid layers were found. Clinical data obtained from the patients showed no modifications on pain, or signs of inflammation in the respective area. In Fig. 6, we see that in 21 days after umbilical hernia surgery with PRF, the mesh is perfectly embedded in the surrounding tissue.

In the groin area, where tension and friction between layers is applied on a regular basis (for example when walking), the embedding process is slowed down (5) (Fig. T).

\section{Discussion}

We observed that there was a difference between PRP and standard procedure. PRP provides just an increased amount of growth factors on site, comparing to PRF which provides in addition a scaffold on the mesh

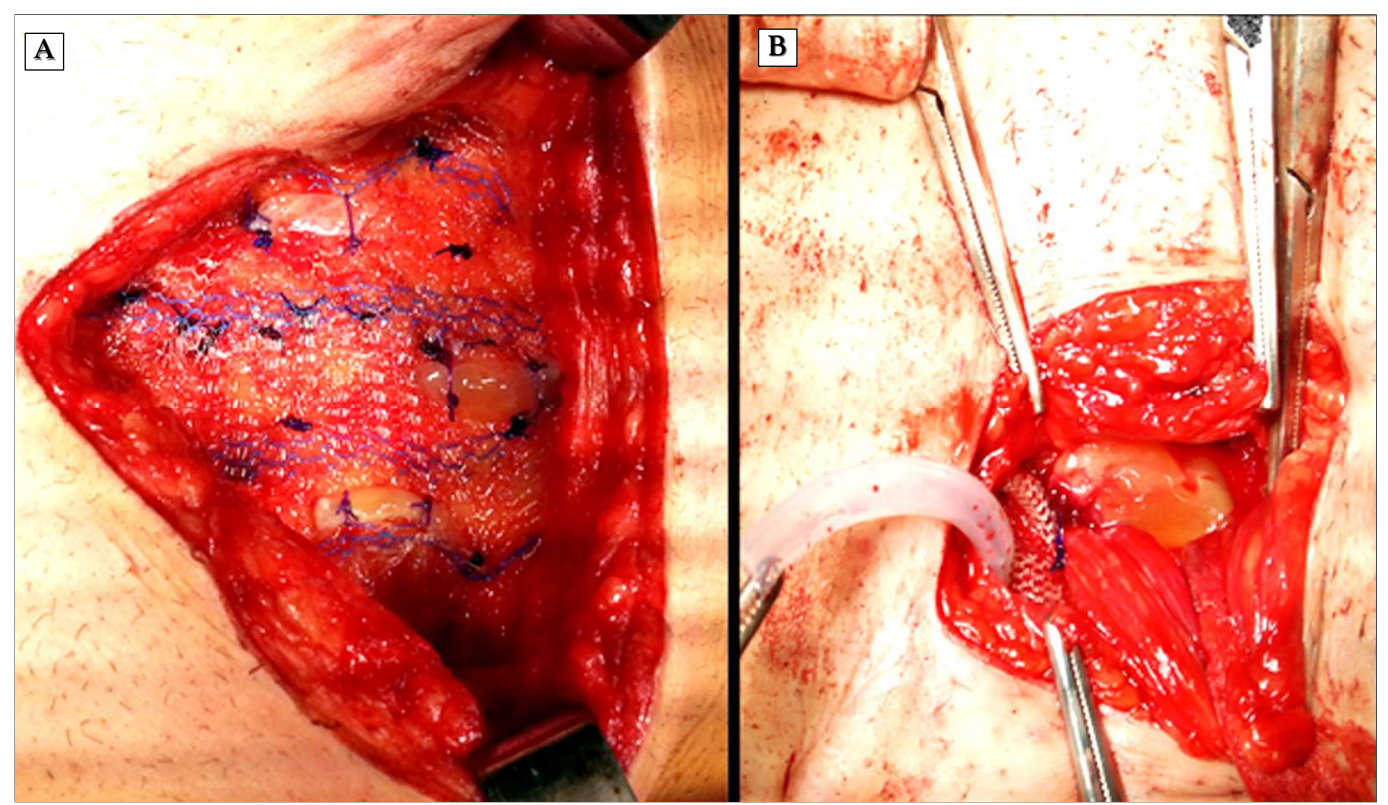

Figure 5. An umbilical hernia after the PP mesh fixation with the attached PRF (A). A small groin hernia repaired using PP mesh covered with PRF (B) 


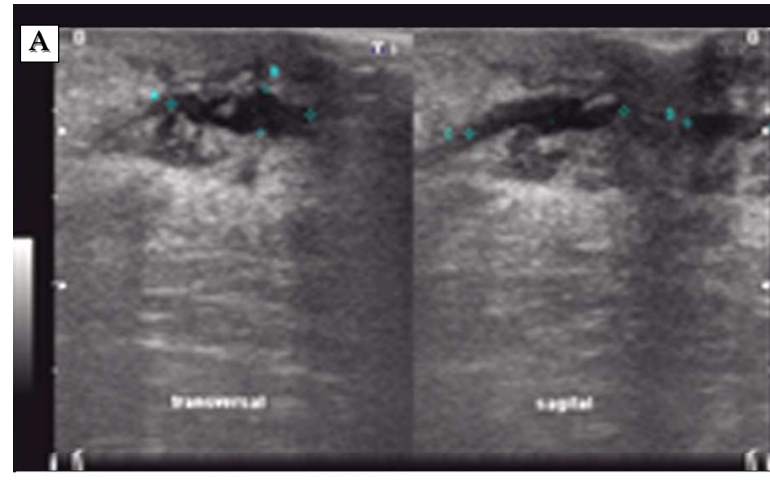

Figure 6. An ombilical hernia first day after implantation (A), at 40 days after the implantation (B) the width of the cavity above the mesh is reduced at almost half and at 60 days after the implant, the ombilical mesh is almost fully integrated (C)

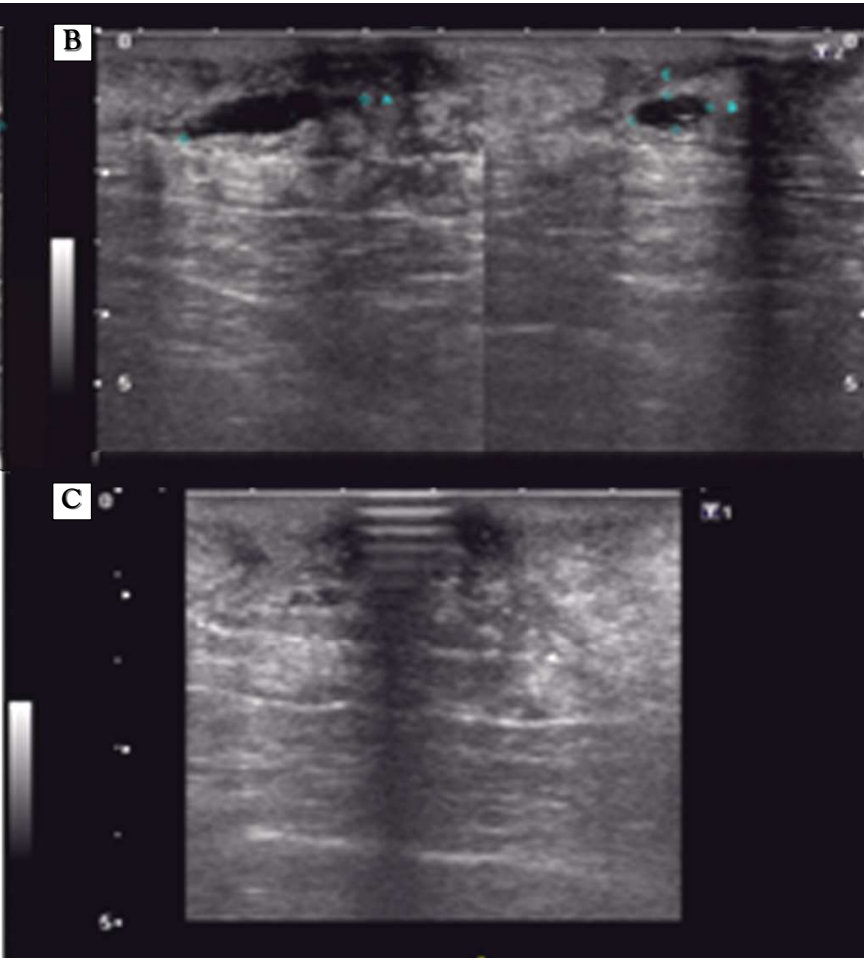

lay mesh technique in abdominal wall defects $(16,18,19,21)$. We will evaluate in further studies, if a full coverage in PRF of the mesh surface will have significant benefit or not.

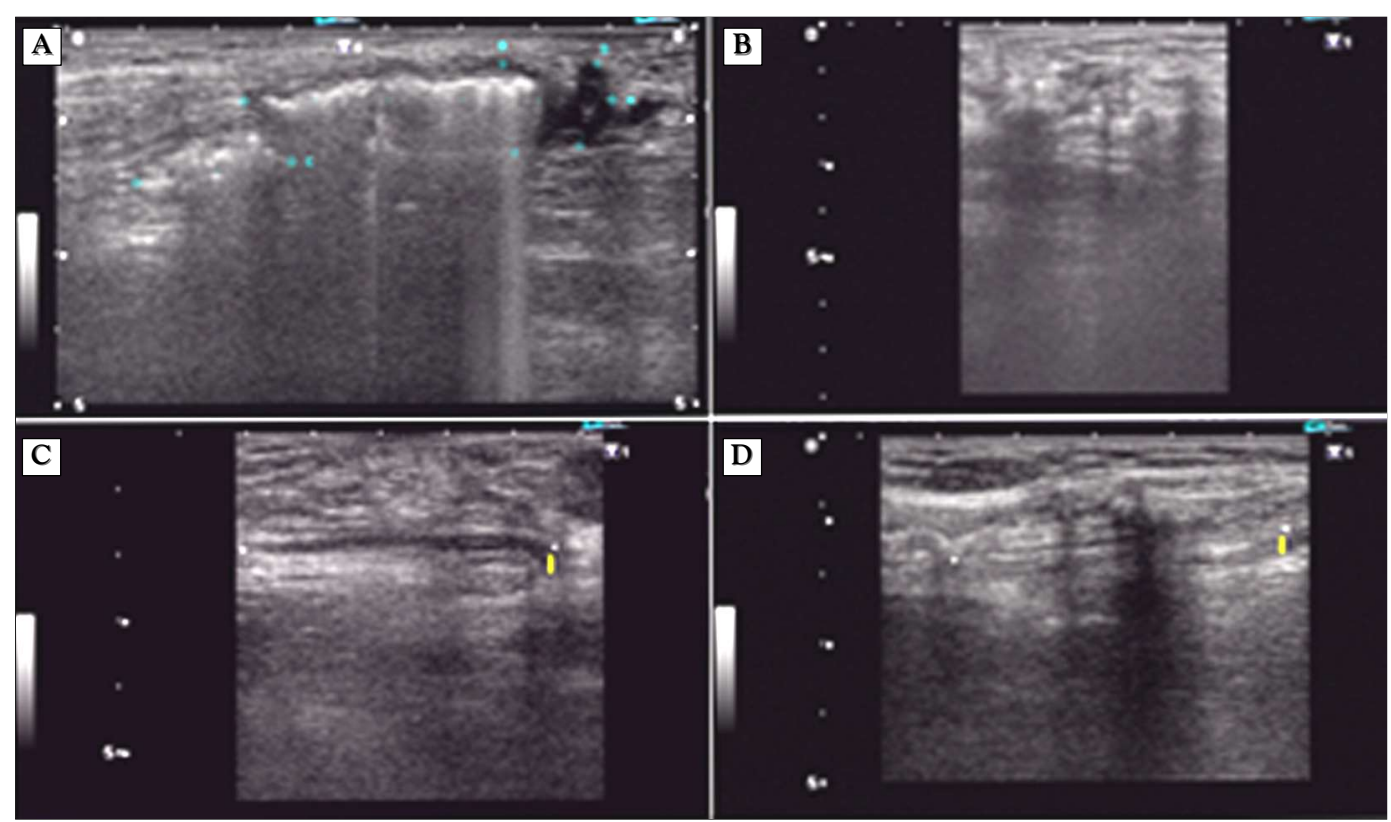

Figure 7. Complete integration of a polypropilene mesh in the surounding tissues at 3 months after surgery. The first image is of the right groin hernia before surgery $(\mathbf{A})$, the second is at 18 days from the procedure $(\mathbf{B})$, at 2 months the mesh is embedded in the tissue with a $4 \mathrm{~mm}$ clivage layer above (C, D) 
Typical early signs of hernia surgery complications include fever and/or flu-like symptoms, prolonged subcutaneous inflammation (redness), swelling, bleeding or drainage from the incision site (22), pain that is resistant to medication or worsening. For long term complication we discuss about chronic pain (lasting more than three months after surgery) (23), nerve damage, abdominal visceral adhesions, chronic infection and biofilms developing on the defective mesh surface (24), mesh shrinkage (25) or migration which can perforate or obstruct abdominal organs, damage to the spermatic cord in men, hernia recurrence.

Every case selected in the study was evaluated as very low or low risk for compartment syndrome (by measuring the defect size, and herniated viscera) to ensure that all the meshes can be placed above the aponeurosis and that no intensive care (ICU) error factors could interfere with the healing process. The compartment syndrome is underestimated when performing on a large size parietal-abdominal defects, with a maximum transverse diameter above $10 \mathrm{~cm}$. This complication is the main risk factor for the development of intraabdominal hypertension which reduces the tissue oxygenation levels that increases the chances of poor healing. A patient at risk of compartment syndrome could benefit from the use of plasma derived components but for the purpose of the study is easier to evaluate the cases without any risk of major complications. In all the augmented cases there were no seroma or other fluid collections complicating the procedure, and no infectious complications.

We had one case of umbilical hernia in which the umbilical skin developed a small area of necrosis developed 5 days after surgery, due to extensive dissection on a very intimate adherent hernia sac, and was solved by excising the necrotic tissue and marginal epidermal regrowth. Another inguinal hernia complicated with intraabdominal bleeding 5 hours after surgery from the reduced content and was resolved by endoscopic ligation and was nonrelated to the augmentation technique.
This is a prospective study that has been recently implemented and these are the preliminary results on a small group for a study designed for one year of enrolling patients and a 1 year follow-up evaluation of patients who consent to the augmented therapy.

Data obtained by our team encouraged our further studies on the augmentation of tissue formation on the mesh implant surface.

\section{Conclusions}

Augmentations of the standard procedure using autologous plasma derived products such as PRP and PRF can improve the healing rate and the integration process of polypropylene meshes in abdominal wall defects without a significant increase of the surgical time, and using autologous components. From the preliminary results PRF proves to be a better choice because it comes with the advantage of generating a proper scaffold for tissue development.

The importance of these small group findings is related to the fact that this technique is fast, and without any other new complications apart from those of the standard procedure. There were no significant data suggesting a different short and medium term complications, data about pain reduction are still under investigation with promising results. Further evaluation in significantly higher groups must be carried out for the proof of data.

\section{Acknowledgements}

These results are part of the "BIOMESH" project financed by the Biomat-INOVA research grant. We would like to thank Dr. Eugeniu Vasile for helping us with the SEM imaging and Vladimir Zamfirescu for the macroscopic pictures.

\section{Conflict of Interest}

This study was in undertaken in partnership with BioSintex Company with no financial benefit. 


\section{Ethics Approval}

\section{The procedure was approved by the Ethical Committee of Colentina Clinical Hospital (approval No. 15/13.07.2017).}

\section{References}

1. Brown CN, Finch JG. Which mesh for hernia repair? Ann R Coll Surg Engl. 2010;92(4):272-8.

2. Muysoms FE, Antoniou SA, Bury K, Campanelli G, Conze J, Cuccurullo D, et al. European Hernia Society guidelines on the closure of abdominal wall incisions. Hernia. 2015;19(1):1-24.

3. Henriksen NA, Yadete DH, Sorensen LT, Tgren MS, Jorgensen LN. Connective tissue alteration in abdominal wall hernia. Br J Surg. 2011; 98(2):210-9.

4. Mastalier BSM, Popescu V, Petrutescu MS, Serafim A, Stancu IC. Evaluations of implanted polypropylene mesh after surgical removal due to eventration or mesh rejection. Mater Plast. 2017:54.49-52.

5. Mavrodin C I, Antoniac VI, Pariza, G. Relationship between Biomaterials Structure Used in Hernia Mesh Fixation and Chronic Infection. Adv. Mater. Res. 2015;1114:278-282.

6. Junge K, Binnebösel M, Rosch R, Otto J, Kämmer D, Schumpelick V, et al. Impact of proinflammatory cytokine knockout on mesh integration. J Invest Surg. 2009;22(4):256-62.

7. Klosterhalfen B, Junge $K$, Hermanns $B$, Klinge $U$. Influence of implantation interval on the long-term biocompatibility of surgical mesh. $\mathrm{Br} J$ Surg. 2002;89(8):1043-8.

8. Argudo N, Pereira JA, Sancho JJ, Membrilla E, Pons MJ, Grande L. Prophylactic synthetic mesh can be safely used to close emergency laparotomies, even in peritonitis. Surgery. 2014;156(5):1238-44.

9. Cevasco M, Itani KMF. Ventral hernia repair with synthetic, composite, and biologic mesh: characteristics, indications, and infection profile. Surg Infect (Larchmt). 2012;13(4):209-15.

10. Miron RJ, Fujioka-Kobayashi M, Bishara M, Zhang $Y$, Hernandez $M$, Choukroun J. Platelet-Rich Fibrin and Soft Tissue Wound Healing: A Systematic Review. Tissue Eng Part B Rev. 2017;23(1):83-99. Epub 2016 Oct 10.

11. Badade P, Mahale S, Panjwani A, Vaidya P, Warang A. Antimicrobial effect of platelet-rich plasma and platelet-rich fibrin. Indian J Dent Res. 2016; 27(3):300-4.

12. Kobayashi E, Flückiger L, Fujioka-Kobayashi M, Sawada K, Sculean A,
Schaller B, et al. Comparative release of growth factors from PRP, PRF, and advanced-PRF. Clin Oral Investig. 2016;20(9):2353-2360.

13. Bai MY, Wang CW, Wang JY, Lin MF, Chan WP. Three-dimensional structure and cytokine distribution of platelet-rich fibrin. Clinics (Sao Paulo). 2017; 72(2):116-124.

14. Hurley ET, Lim Fat D, Moran CJ, Mullett H. The Efficacy of Platelet-Rich Plasma and Platelet-Rich Fibrin in Arthroscopic Rotator Cuff Repair: A Meta-analysis of Randomized Controlled Trials. Am J Sports Med. 2019; 47(3):753-761. Epub 2018 Feb 21.

15. Ubbink DT, Santema TB, Stoekenbroek RM. Systemic wound care: a metareview of cochrane systematic reviews. Surg Technol Int. 2014; 24:99-111.

16. Lundquist R, Dziegiel MH, Tgren MS. Bioactivity and stability of endogenous fibrogenic factors in platelet-rich fibrin. Wound Repair Regen. 2008;16(3):356-63.

17. Masuki H, Okudera T, Watanebe T, Suzuki M, Nishiyama K, Okudera H, et al. Growth factor and pro-inflammatory cytokine contents in platelet-rich plasma (PRP), plasma rich in growth factors (PRGF), advanced platelet-rich fibrin (A-PRF), and concentrated growth factors (CGF). Int J Implant Dent. 2016;2(1):19.

18. Arora S, Kotwal U, Dogra M, Doda V. Growth Factor Variation in Two Types of Autologous Platelet Biomaterials: PRP Versus PRF. Indian J Hematol Blood Transfus. 2017;33(2):288-292. Epub 2016 Sep 6.

19. Pinto NR, Ubilla M, Zamora Y, Del Rio V, Dohan Ehrenfest DM, Quirynen M. Leucocyte- and platelet-rich fibrin (L-PRF) as a regenerative medicine strategy for the treatment of refractory leg ulcers: a prospective cohort study. Platelets. 2018;29(5):468-475. Epub 2017 Jul 20.

20. Naik B, Karunakar P, Jayadev M, Marshal VR. Role of Platelet rich fibrin in wound healing: A critical review. J Conserv Dent. 2013;16(4):284-93.

21. Choukroun J, Diss A, Simonpieri A, Girard M0, Schoeffler C, Dohan SL, et al. Platelet-rich fibrin (PRF): A second-generation platelet concentrate. Part IV: Clinical effects on tissue healing. Oral Surgery, Oral Med. Oral Pathol. Oral Surg Oral Med Oral Pathol Oral Radiol Endod. 2006; 101(3): e56-60.

22. Bleier JIS, Resnick AS. Complications of Incisional Hernia Repair. Semin. Colon Rectal Surg. 2009;20:125-130.

23. Kurzer M, Kark A, Hussain ST. Chronic Pain After Open Mesh Repair of Incisional Hernia. Hernia Repair Sequelae pp 221-225I Cite as

24. Mavrodin C, Antoniac VI, Pariza G. Relationship between Biomaterials Structure Used in Hernia Mesh Fixation and Chronic Infection Relationship between biomaterials structure used in hernia mesh fixation and chronic infection. Advanced Materials Research. 2015. doi:10.4028/ www.scientific.net/AMR.1114.278

25. Socea B, Socea LI, Bratu OG, Mastalier B, Dimitriu M, Carap A, Constantin VD et al. Recurrence Rates and Mesh Shrinkage After Polypropylene vs. Polyester Mesh Hernia Repair in Complicated Hernias. Mat Plastice. 2018;55(1):79-81 